\title{
Analysis of Human Development Index: Concept and Factors that Influence North Sumatera Province
}

\author{
Eko Wahyu Nugrahadi \\ Department of Economics \\ State University Of Medan \\ Medan, Indonesia \\ ewahyunugrahadi@yahoo.com
}

Abstract-In 2010 the United Nations Development Program (UNDP) re-issued a new version by changing the methodology of calculating the Human Development Index (HDI) from Adult Literacy Rate (ALR) to Expected Year of Schooling (EYS). This improvement is expected to be able one of important indicators in the effort to build the quality of human life and improve the standard of Human Development Index. This study aims to see the impact of unemployment, per capita income, education, and health in influencing the human development index in North Sumatra. The method of analysis that used in this research is Error Correction Model (ECM) method to see the short and long-term influence among research variables. The results showed that the value of ECT coefficient on the model have significant and negative for estimation of Human Development Index. The ECM results also showed that in the short and long-term the variables that used in this study significantly influence the human development index. If per capita income, education, and healthy increase as well s the decrease of the unemployment rate, it can be raising the good human development in North Sumatera.

Keywords- Human Development Index, Total Unemployment, Per Capita Income, Education, Health

\section{INTRODUCTION}

Development is one of the processes to increase a good economic quality, Government efforts in development also aimed to create wealth and public welfare. The indicator to measure it was Human Development Index [1] because human development had defined as an effort to expand people choices through empowerment stages which accentuated basic human power so they could fully participate in every development field [2]. Since HDI measured enacted, development orientation did not just focus on economic growth, but rather to human as a basic element to achieve sustainable development [3]. The Human Development Index (HDI) aims to provide a broader characterization of "development" that is possible by focusing on national income alone. For this purpose, the index aggregates country-level attainments in life expectancy and education, as well as income [4].

In 2010 United Nations Development Program (UNDP) had re-issued the new version by changing the measurement methodology of Human Development Index from Literacy

\author{
Muammar Rinaldi \\ Student of postgraduate degree Economics \\ State University Of Medan \\ Medan, Indonesia \\ rinaldy@mhs.unimed.ac.id
}

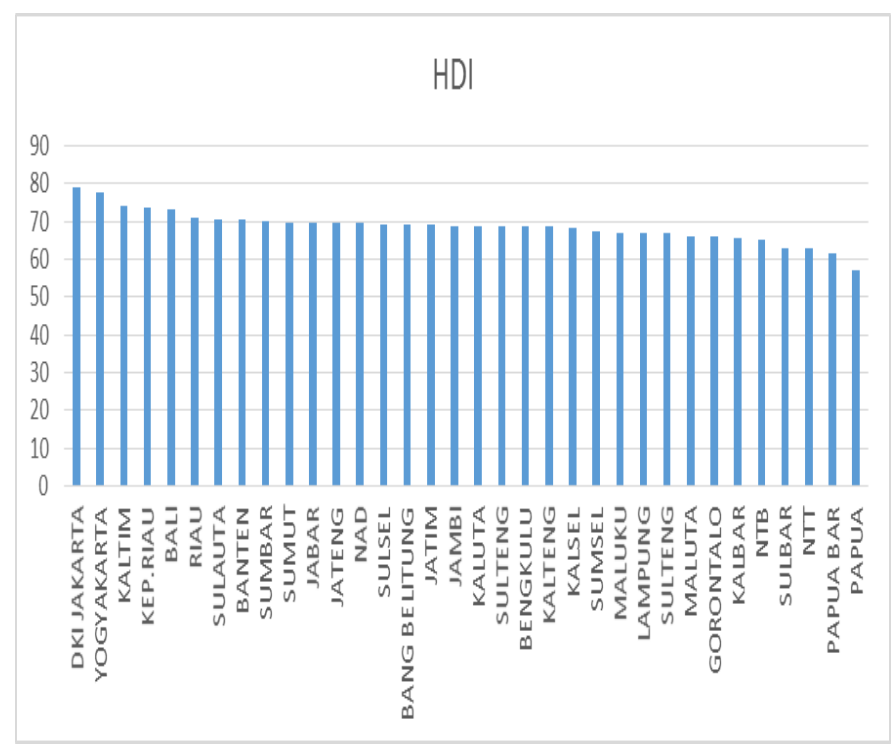

Fig. 1: 2015 Human Development Index In Indonesia

Source: Processed from BPS, 2016

Rate to Expected Years Of Schooling. This update hoped it could be one of the important indicators in the effort to developing Quality of Life and to increase the standard of Human Development Index. North Sumatera human Development Index in 2015 categorized in low position because it was in the 10th position from 34 Provinces in Indonesia with a percentage of $69.51 \%$ [5]. If compared with other provinces in Sumatera, North Sumatera was in 4th position but still below from Kepulauan Riau, Riau, and West Sumatera. The complete 2015 Human Development Index in Indonesia as below

From the graph above, we can see the province which made to achieve high Human Development status was DKI Jakarta. North Sumatera Human Development Index from 2011 to 2015 had significantly increased, but the increase itself was not be helping to achieve high development status. 


\section{HDI}

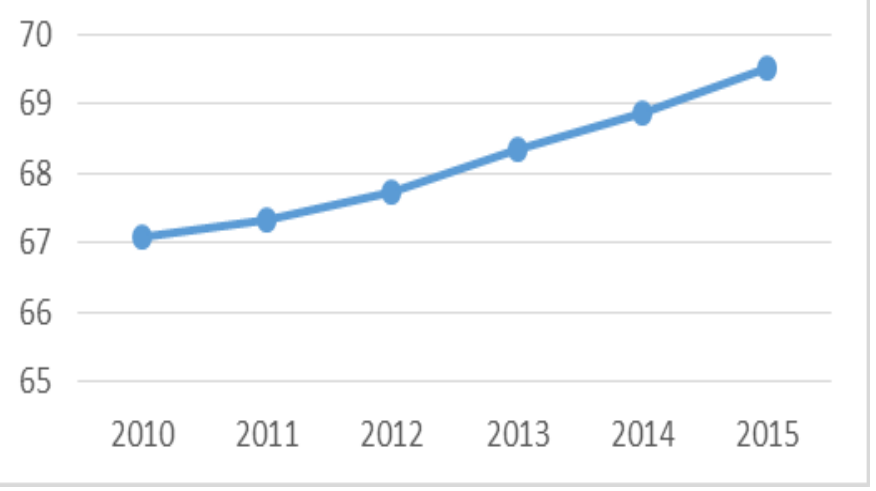

Fig. 2: North Sumatera Human Development Index Trend from 2010 to 2015

Source: Processed from BPS, 2016

The Human Development above the achievement means to expand the opportunity. This thing in line with North Sumatera development priority which one of them was public welfare which the components were education stages, per capita income, employment, health rate, etcetera [5].

Human development index is a concise measuring tool for assessing progress in three basic dimensions of human development, e.g a long and healthy life, access to appropriate knowledge and living standards. A long and healthy life can be measured by life expectancy at birth. The level of knowledge is also measured by the average year of education among the adult population, which is the average number of years of education received in the lifetime by people aged 25 years and over [6].

The value of human capital (Human Capital) nation is not only determined by the total population, or unskilled labor (labor intensive) but had been determined by the intellectual labor (Brain intensive). Adam Smith (1952), a classical economist, acknowledged that education and training will be able to improve the knowledge and skills which in turn will be able to increase work productivity. He said that the welfare and wealth of a nation are depending on intelligence and intellectual superiority [7].

The ultimate aim of education policies is to speed development by strengthening investment in human capital, [8]. Human development successes could be seen by how people basic problem had resolved. Those problems are poverty and unemployment also there is no access to education and health facility. Education Index itself is one of the variables of Human Development determinant. Education itself is not just about formal education which demanding personal to followed teaching and learning process in formal schools. Government and education institutions have to be more focused on education quality which is still stagnant for now. Education rank in Indonesia itself is $57^{\text {th }}$ in the world, [7]. In this case, the indicators are mean years of schooling, and expected years of schooling, [5]. Mean Years of Schooling of North Sumatera in 2015 was quite high for 9,03 years compared to national mean years of schooling for just 7,84 years. North Sumatera Mean Years of Schooling was in number five for national rank. Meanwhile, expected years of schooling in North Sumatera was 12,82 years higher than national with its expected years of schooling was 12,55 years, also made expected years of schooling in North Sumatera in the middle to top position which was the $13^{\text {th }}$ position for national. Those two indicators must be increased to achieve the public welfare.

Health rate also has a role in human development, the higher health rate in North Sumatera, hoped the opportunity to survive would increase. A Longer life is a dream of all the people, one of the factors to achieve that is better health The long life proxy and health in human development is to see life expectancy when born, [9]. Life expectancy indicator was one of the indicators that usually used to evaluate development performance in the health field.

In addition, to fixing the education quality, next effort to make people wealthy is to reduce the unemployment rate, especially in North Sumatera. Employment situation of North Sumatera in August 2015 was open unemployment rate had $6.71 \%$ or as much as 424,794 people who had a status as unemployment or job seeker. This situation increased if compared with August 2014 which open employment at that time was $6.23 \%$ [5]. This situation made low public per capita income in North Sumatera and would make worst the human development situation.

\section{RESEARCH METHODS}

This Human Development Index study and its impact factor were using secondary data from Badan Pusat Statistik Sumatera Utara. This research aims to see how much employment, per capita income, education, and health will determine Human Development Index. Education and health data were according to an indicator of Human Development Index itself. The data type in this research was using time series data from 2010-2015 and interpolated becomes quarterly. Considering time series data have potency become non-stationer, that this research had a plan using Error Correction Model which aimed to see the short and long-term impact because there is cointegration between variables research.

Error Correction Model (ECM) is one of the dynamic linear models former to avoid spurious regression, [10]. There are three reasons why dynamic linear models have been used, first, psychological reasons; second, technological reasons; and reason number three is institutional reasons, [11]. According to those reasons, institutional has an important role in economic. This matter mirrored in short and long-term economic methodology.

Before doing ECM estimation and descriptive analysis, several stages must being done like as unit root test, cointegration degree test, and cointegration test. Steps in ECM model, [12]: 


\section{A. Unit Root Test}

A Concept which had been used to test stationer of certain time series data is unit root test. If certain time series data tend to be not stationer, thus those data had a unit root problem. The unit root problem existences could see by comparing statistic value from regression and Augment Dickey-Fuller test value.

\section{B. Integration Degree Test}

If in unit root test of time series data was stationer, then the next step is doing integration degree test to be known in how many the data degree would be stationer.

\section{Cointegration Test}

The most often test which has been used are EngleGranger Test (EG), Augmented Engle-Granger Test (AEG) and Durbin-Watson Cointegrating Regression Test (CRDW). To get AG value, AEG and CRDW arithmetic, data to be used have to integrate with an equal degree.

\section{Error Correction Model (ECM)}

If passed from cointegration test, the next test is using the dynamic linear model to know the possibility of structural changes, because the long-term balance correlation between dependent and independent variable from cointegration test value will not be valid every time. ECM process in Human Development equation:

$\Delta \mathrm{HDI}=\alpha_{0}+\alpha_{1} \Delta \mathrm{Y}_{\mathrm{t}}-\alpha_{2} \Delta \mathrm{Unp}_{\mathrm{t}}+\alpha_{3} \Delta \mathrm{Ed}_{\mathrm{t}}+\alpha_{4} \Delta \mathrm{He}_{\mathrm{t}}+\alpha_{5} \mathrm{e}_{\mathrm{t}-1}+\mathrm{e}_{\mathrm{t}}$ Ket.

HDI = Human Development Index, Y= Per capita Income, $\mathrm{Unp}=$ Total Unemployment, $\mathrm{Ed}=$ Education, $\mathrm{He}=$ Health .

\section{RESULTS AND DISCUSSIONS}

Human Development Index is one of the indicators which will give a general description of development achievement and the priorities determiner from development achievement from a region especially North Sumatera. One of those priorities was human welfare, covering education stages, per capita income, employment, health, and etcetera. Human Development Index in Sumatera Utara from the last five years was significant increases. But with high unemployment and there is education gap as well as health gap, obstructed Human Development Index in North Sumatera into high category.

TABLE I. DESCRIPTION OF HDI, TOTAL UNEMPLOYMENT, PER CAPITA InCOME, EDUCATION, HEALTH IN SUMATERA UTARA

\begin{tabular}{|l|r|r|r|r|r|}
\hline Year & HDI & $\begin{array}{c}\text { Total } \\
\text { Unemployment }\end{array}$ & $\begin{array}{c}\text { Per Capita } \\
\text { Income }\end{array}$ & Education & Health \\
\hline 2010 & 67,09 & 491806 & 946478,09 & 8,51 & 67,46 \\
\hline 2011 & 67,34 & 402125 & 957478,09 & 8,61 & 67,63 \\
\hline 2012 & 67,74 & 379982 & 375924,14 & 8,72 & 67,81 \\
\hline 2013 & 68,36 & 412202 & 398779,25 & 8,79 & 67,94 \\
\hline 2014 & 68,87 & 390712 & 419649,28 & 8,93 & 68,04 \\
\hline 2015 & 69,51 & 428794 & 440955,85 & 9,03 & 68,29 \\
\hline
\end{tabular}

To see short and long-term impact of unemployment, per capita income, education, and health toward Human Development Index using ECM model, the result was there is impact between short and long-term with the following process:

\section{A. Unit Root Test}

TABLE II. RESUlT OF UNIT ROOT TEST

\begin{tabular}{|l|c|c|c|c|c|c|}
\hline \multirow{2}{*}{$\begin{array}{c}\text { VARI } \\
\text { ABLE }\end{array}$} & $A D F$ & LEVEL & $A D F$ & $\begin{array}{c}1^{\text {st }} \\
\text { Difference }\end{array}$ & $A D F$ & $\begin{array}{c}2^{\text {st }} \\
\text { Differen } \\
\text { ce }\end{array}$ \\
\hline HDI & -1.877 & 0.3358 & -2.617 & 0.1047 & -5.588 & 0.0002 \\
\hline Unp & -1.676 & 0.4285 & -1.729 & 0.4034 & -5.685 & 0.0002 \\
\hline $\mathrm{Y}$ & -1.7108 & 0.4116 & -4.156 & 0.0064 & -14.966 & 0.0000 \\
\hline $\mathrm{Ed}$ & 0.462 & 0.9803 & -3.999 & 0.0070 & -5.835 & 0.0001 \\
\hline $\mathrm{He}$ & 1.362 & 0.9981 & -0.427 & 0.8878 & -4.992 & 0.0007 \\
\hline
\end{tabular}

To know the time series data had stationer or not, we wiil use unit root test. The unit root test is Dicky Fuller method, with the following hypothesis:

- H0: There is unit root

- H1: There is no unit root

The resulting form this research is there is no unit root, and the data was stationer.

From the table above shows if stationer data was in second stage difference because all of the variables has a statistic for $\mathrm{ADF}<0,05$

\section{B. Cointegration Test}

The result of cointegration test obtained from forming residual which getting from regressing independent variable toward dependent variable using OLS. That residual must be stationed in the level stage to be said had cointegration.

The result of Cointegration Test:

Null Hypothesis: ECT has a unit root

Exogenous: Constant

Lag Length: 1 (Automatic - based on SIC, maxlag=4)

\begin{tabular}{lccc}
\hline \hline & t-Statistic & Prob.* \\
\hline \hline Augmented Dickey-Fuller test statistic & -2.189977 & 0.2155 \\
\hline Test critical values: & $1 \%$ level & -3.808546 & \\
& $5 \%$ level & -3.020686 & \\
& $10 \%$ level & -2.650413 & \\
\hline \hline
\end{tabular}

*MacKinnon (1996) one-sided p-values.

Augmented Dickey-Fuller Test Equation

Dependent Variable: D(ECT)

Method: Least Squares

Date: 06/19/17 Time: 11:06

Sample (adjusted): 2011Q1 2015Q4

Included observations: 20 after adjustments 


\begin{tabular}{lrlll}
\hline \hline \multicolumn{1}{c}{ Variable } & Coefficient & Std. Error & t-Statistic & Prob. \\
\hline \hline \multicolumn{1}{c}{ ECT(-1) } & -0.285073 & 0.130172 & -2.189977 & 0.0428 \\
D(ECT(-1)) & 0.551626 & 0.205368 & 2.686044 & 0.0156 \\
$\quad$ C & -0.000124 & 0.001830 & -0.067820 & 0.9467 \\
\hline \hline \multirow{2}{*}{ R-squared } & 0.349339 & Mean dependent var & -0.000559 \\
Adjusted R-squared & 0.272791 & S.D. dependent var & 0.009551 \\
S.E. of regression & 0.008144 & Akaike info criterion & -6.645483 \\
Sum squared resid & 0.001128 & Schwarz criterion & -6.496123 \\
Log likelihood & 69.45483 & Hannan-Quinn criter. & -6.616327 \\
F-statistic & 4.563638 & Durbin-Watson stat & 2.308125 \\
Prob(F-statistic) & 0.025913 & & \\
\hline \hline
\end{tabular}

From the result above we can see if there is no cointegration because the residual does not stationer in the level stage, seen that from ADF the Probability was 5\% higher. To making residual has cointegration, then the model had made become double log, estimation result:

Null Hypothesis: ECT1 has a unit root

Exogenous: Constant

Lag Length: 0 (Automatic - based on SIC, maxlag=4)

\begin{tabular}{lccc}
\hline \hline & t-Statistic & Prob.* \\
\hline \hline Augmented Dickey-Fuller test statistic & -3.189405 & 0.0351 \\
\hline Test critical values: & 1\% level & -3.788030 & \\
& 5\% level & -3.012363 & \\
& 10\% level & -2.646119 & \\
\hline \hline
\end{tabular}

*MacKinnon (1996) one-sided p-values.

Augmented Dickey-Fuller Test Equation

Dependent Variable: D(ECT1)

Method: Least Squares

Date: 06/19/17 Time: 15:46

Sample (adjusted): 2010Q4 2015Q4

Included observations: 21 after adjustments

\begin{tabular}{lrlrr}
\hline \hline \multicolumn{1}{c}{ Variable } & Coefficient & Std. Error & t-Statistic & Prob. \\
\hline \hline \multicolumn{1}{c}{ ECT1(-1) } & -0.584979 & 0.183413 & -3.189405 & 0.0048 \\
$\quad$ C & 0.000464 & 0.001158 & 0.400970 & 0.6929 \\
\hline \hline R-squared & 0.348697 & Mean dependent var & 0.000872 \\
Adjusted R-squared & 0.314418 & S.D. dependent var & 0.006370 \\
S.E. of regression & 0.005274 & Akaike info criterion & -7.561506 \\
Sum squared resid & 0.000529 & Schwarz criterion & -7.462028 \\
Log likelihood & 81.39581 & Hannan-Quinn criter. & -7.539917 \\
F-statistic & 10.17230 & Durbin-Watson stat & 1.887372 \\
Prob(F-statistic) & 0.004827 & & \\
\hline \hline
\end{tabular}

The result above shows if data had cointegration, because ADF Prob. 0,0351<0,05.

\section{Eror Correction Model (ECM)}

$\mathrm{D}(\log (\mathrm{HDI}))=\alpha_{0}-\alpha_{1} \mathrm{D}(\log (\mathrm{Unp}))+\alpha_{2} \mathrm{D}(\log (\mathrm{Y}))+$ $\alpha_{3} \mathrm{D}(\log (\mathrm{Edu}))+\alpha_{4} \mathrm{D}(\log (\mathrm{He}))+\mathrm{ECT}(-1)+\mathrm{e}$

Dependent Variable: D(LNIPM)

Method: Least Squares

Date: 06/27/17 Time: 19:23

Sample (adjusted): 2010Q4 2015Q4

Included observations: 21 after adjustments

\begin{tabular}{lrrrr}
\hline \hline \multicolumn{1}{c}{ Variable } & Coefficient & Std. Error & t-Statistic & Prob. \\
\hline \hline D(LOGUNP) & -1.154160 & 0.378766 & -3.047159 & 0.0082 \\
D(LOGY) & 0.358129 & 0.060332 & -5.935980 & 0.0000 \\
D(LOGEDU) & 2.036559 & 1.047654 & -1.943924 & 0,0509 \\
D(LOGHE) & 1.234245 & 0.472894 & 2.609980 & 0.0197 \\
ECT1(-1) & -0.337459 & 0.159595 & -2.114472 & 0.0516 \\
C & 0.009271 & 0.003731 & 2.484956 & 0.0252 \\
\hline \hline R-squared & 0.728850 & Mean dependent var & 0.002714 \\
Adjusted R-squared & 0.638466 & S.D. dependent var & 0.006423 \\
S.E. of regression & 0.003862 & Akaike info criterion & -8.040195 \\
Sum squared resid & 0.000224 & Schwarz criterion & -7.741760 \\
Log-likelihood & 90.42205 & Hannan-Quinn criter. & -7.975427 \\
F-statistic & 8.063980 & Durbin-Watson stat & 2.282679 \\
Prob(F-statistic) & 0.000725 & & \\
\hline \hline
\end{tabular}

$\mathrm{D}(\log (\mathrm{HDI}))=0,009271-1,154160 * \mathrm{D}(\log (\mathrm{Unp}))+0,358129 *$

$\mathrm{D}(\log (\mathrm{Y}))+2,036559 * \mathrm{D}(\log (\mathrm{Edu}))+1,234254 * \mathrm{D}(\log (\mathrm{He}))-$ $0,337459 * \mathrm{ECT}(-1)+\mathrm{e}$

The result above shows if ECT coefficient value in those models had significant and negative for Human Development Index estimation. We could conclude that if above ECM value shows in short and long term, variables which used in this research had impact significantly toward Human Development Index with R2 value for 0,728 or $72.8 \%$. And then it can be said that dependent variables which included were right to seen impact from Human Development Index.

\section{CONCLUSIONS}

A number of unemployment has a role to increase Human Development Index, the higher government's efforts to combat unemployment in North Sumatera; it will increase Human Development Index in North Sumatera.

Per capita income, education and health as well were very determining into the growth of Human Development Index, the better educational and health equality as well as income from North Sumatera people it will help to increases Human Development Index. The impact which had given from independent variable from this research toward human development index was $72,8 \%$.

\section{References}

[1] BPS. 2016. Human Development Index 2015. Jakarta: BPS 
[2] UNDP. 2011. Human Development Report 2011. New York: Oxford University Press.

[3] UNDP. 1990. Human Development Report 1990. New UNDP. 1990. Human Development Report 1990. New York: Oxford University Press

[4] Revallion, Martin. 2012. Troubling tradeoffs in the Human Development Index. Journal of development economics 99. 201-209

[5] BPS. 2016. Human Development Index of North Sumatera 2015. Jakarta: BPS

[6] UNDP. 2016. Human Development Report 2016, Human Development for Everyone. New York : Oxford University Press

[7] Rinaldi. 2017. Education is as the encouragement of the increasing of human development index in Indonesia. https://www.researchgate.net/publication/318654424
[8] Schaffner, Julie. 2014. Education. Development Economics (pp. 496). Retrieved from https://www.ebook3000.com

[9] BPS. 2017. Human Development Index 2016. Jakarta: BPS

[10] Insukindro. 1998. Sindrum R2 Dalam Analisis Regresi Linier Runtun Waktu. Jurnal Ekonomi dan Bisnis Indonesia. Vol.13, No.41 1-11

[11] Gujarati, Damodar N. 1995. Basic Econometrics. Thir Edition. Mc. Graw-Hill, Singapore

[12] Basuki, Agus Tri. 2014. Regresi Model PAM, ECM, dan Data Panel. Yogyakarta: KDT 